\title{
Minimally invasive approach to the adrenal gland in obese patients with Cushing's syndrome
}

Monica Ortenzi, Andrea Balla, Roberto Ghiselli, Roberto Vergari, Gianfranco Silecchia, Emanuele Guerrieri, Alessandro Maria Paganini \& Mario Guerrieri

To cite this article: Monica Ortenzi, Andrea Balla, Roberto Ghiselli, Roberto Vergari, Gianfranco Silecchia, Emanuele Guerrieri, Alessandro Maria Paganini \& Mario Guerrieri (2019): Minimally invasive approach to the adrenal gland in obese patients with Cushing's syndrome, Minimally Invasive Therapy \& Allied Technologies, DOI: 10.1080/13645706.2018.1536669

To link to this article: https://doi.org/10.1080/13645706.2018.1536669

册Published online: 19 Jan 2019.

Submit your article to this journal $\sqsubset \pi$

View Crossmark data ־ 


\title{
Minimally invasive approach to the adrenal gland in obese patients with Cushing's syndrome
}

\author{
Monica Ortenzi ${ }^{a}$, Andrea Balla ${ }^{b}$ (D), Roberto Ghiselli ${ }^{a}$, Roberto Vergari ${ }^{a}$, Gianfranco Silecchiac, \\ Emanuele Guerrieri $^{\mathrm{a}}$, Alessandro Maria Paganini ${ }^{\mathrm{b}}$ and Mario Guerrieri ${ }^{\mathrm{a}}$ \\ ${ }^{a}$ Clinica Chirurgica, Universita Politecnica delle Marche, Ancona, Italy; ${ }^{b}$ Department of General Surgery and Surgical Specialties \\ "Paride Stefanini", Sapienza University of Rome, Rome, Italy; 'Department of Medical-Surgical Sciences and Biotechnologies, Division \\ of General Surgery and Bariatric Centre of Excellence, Sapienza University of Rome, Rome, Italy
}

\begin{abstract}
Introduction: The combination of Cushing's syndrome and obesity, one of the most common manifestations of the syndrome itself, may be associated with the worsening of post-operative outcomes in case of laparoscopic adrenalectomy. This study focused on the laparoscopic treatment of Cushing's syndrome with the purpose to identify any relevant difference between morbidly obese, mildly obese and non-obese patients.

Material and methods: Patients were retrospectively divided into three groups according to their Body Mass Index (BMI). Demographic characteristics, operative and post-operative data were collected. Data about different hemostatic devices were also collected and compared. Differences were analyzed with the Fisher's exact test for categorical variables, and the MannWhitney test for continuous variables.

Results: No differences were found in operative time $(101.5 \pm 50.9 \mathrm{~min} ; p=.919)$, conversion rate $(2.6 \% ; p=.655)$ or length of stay $(4.3 \pm 2.9$ days; $p=.886)$. Complication rate was $3 \%(p=.32)$, without any mortality. $95 \%$ of patients showed a complete resolution of hypercotisolyismrelated symptoms, and a mean BMl reduction of $5 \pm 3.2 \mathrm{~kg} / \mathrm{m}^{2}$ (follow up $=6.3 \pm 4.2$ years). Conclusions: Laparoscopic adrenalectomy is safe and feasible in obese patients affected with Cushing's disease and it can lead to the resolution of the related symptoms.
\end{abstract}

\section{ARTICLE HISTORY}

Received 20 February 2018

Accepted 11 September 2018

\section{KEYWORDS}

Laparoscopic adrenalectomy; obesity; Cushing

\section{Introduction}

Cushing's syndrome results from chronic exposure to excess glucocorticoids, which, from any cause, induces a plethora of complications that ultimately impact life expectancy [1]. The therapeutic goal is to normalise tissue exposure to cortisol to reverse increased morbidity and mortality. Adrenal functioning mass accounts for the 20 to $27 \%$ of cases of non-iatrogenic hypercortisolism [2,3]. Optimum treatment should allow eventual normalisation of the hypothalamicpituitary-adrenal axis and maintenance of pituitary function, and, when an adrenal mass is identified, its resection constitutes the standard of cure [1]. When symptomatic Cushing's syndrome includes different pathognomonic signs and, besides "moon facies", increased blood pressure, thinning fragile skin and purple striae, central obesity is one of the most characteristic [4].

Concerns arose regarding the application of laparoscopic adrenalectomies in the treatment of morbidly obese patients due to extremely limited working spaces and the confirmed association between postoperative complications and obesity [5-7].

This study focused on the laparoscopic treatment of Cushing's syndrome with the purpose to find any relevant differences between morbidly obese, mildly obese and non-obese patients.

\section{Material and methods}

A retrospective analysis of patients undergoing laparoscopic adrenalectomy for Cushing's disease was performed. Patients were extracted from the databases of the Surgical Clinic of Polytechnic University of Marche and the Department of General Surgery and Surgical Specialties, "Paride Stefanini", Sapienza University of Rome.

The preoperative assessment included abdominal computed tomography (CT) and a complete endocrine evaluation that included: blood and 24-h urine analysis to measure fasting glucose; serum cortisol at 
8:00 $\mathrm{AM}$ and after $1 \mathrm{mg}$ dexamethasone; adrenocorticotropic hormone stimulation test; 17hydroxyprogesterone; dehydroepiandrosterone; and 24-h urinary-free cortisol excretion.

Values of urinary free cortisol (UFC) levels $>70 \mu \mathrm{g}$ per $24 \mathrm{~h}(193 \mathrm{nmol}$ per $24 \mathrm{~h}$; normal values $10-70 \mu \mathrm{g}$ per $24 \mathrm{~h}, 28-193 \mathrm{nmol}$ per $24 \mathrm{~h}$ ), serum cortisol levels after $1 \mathrm{mg}$ dexamethasone suppression test $(\mathrm{DST})>3.0 \mu \mathrm{g} / \mathrm{dl} \quad(83 \mathrm{nmol} / \mathrm{liter}) ; \quad$ and morning $(0800 \mathrm{~h})$ ACTH (AdrenoCorticotrip Hormone) levels $<10 \mathrm{pg} / \mathrm{ml}(2.2 \mathrm{pmol} /$ liter $)$ were considered as cut-off to define adrenal hypercotisolism $[1,8-10]$.

The association of at least two of these parameters was considered as diagnostic for subclinical Cushing's disease [10]. At CT all adrenal masses looked homogeneous and hypodense and with well-shaped features, consistent with the diagnosis of an adrenocortical adenoma.

The patients were divided into three groups according to their Body Mass Index (BMI): BMI $<25 \mathrm{Kg} / \mathrm{m}^{2}, \quad 25<\mathrm{BMI}<30 \mathrm{Kg} / \mathrm{m}^{2}$ and $\mathrm{BMI}$ $>30 \mathrm{Kg} / \mathrm{m}^{2}$.

In all patients, the diagnosis of pheochromocytoma and aldosteronoma was excluded by appropriate hormonal dosages $(24 \mathrm{~h}$ urinary catecholamines and upright plasma renin activity and aldosterone). Exclusion criteria were multiple laparotomic abdominal interventions and evidence of tumour invasion and/or lymph node involvement.

The transperitoneal approach was adopted for all operations. The patient was placed in supine position for anterior access and in lateral decubitus position for flank approach procedures. The operating technique has been described elsewhere [11].

Type of approach as well as intraoperative and post-operative complications were recorded.

Adrenal gland was measured after being excised and the maximum diameter was considered.

Moreover, patients were utterly divided with regard to the type of haemostatic device used for dissection and division of adrenal vascular pedicle.

All patients receiving monolateral adrenalectomy were given escalating doses of oral corticosteroids in the two weeks following the operation.

The improvement or worsening of BMI, arterial blood pressure and fasting glucose were established at 18 months and at the last follow-up. The improvement or worsening of BMI was defined by a change $>5 \%$ of BMI, respectively, between baseline and the end of the follow-up period [12].

The improvement or worsening of arterial blood pressure was defined as, during the follow-up period, patients passed from prehypertension category to another or the hypertensive patients from a hypertension grade to another, according the Guidelines for the Management of Arterial Hypertension of the European Society of Cardiology [13].

\section{Statistical analysis}

Quantitative variables were presented as mean and standard deviation ( \pm SD) into brackets, and compared using the Kruskal-Wallis test. Absolute and percentage frequencies were used to present qualitative variables, and Fisher exact test was adopted to compare them. Logistic regression analysis was performed to evaluate the effect of clinical and demographic characteristics on operating time. Statistical significance was assessed at a level of probability of 0.05 .

\section{Results}

A total of 228 patients, from 1994 to 2017, were included. Sixty two patients (27.2\%) had a BMI $>25 \mathrm{~kg} / \mathrm{m}^{2} \quad\left(\right.$ mean $\left.=23.6 \mathrm{Kg} / \mathrm{m}^{2}\right)$, in 87 patients $(38.2 \%)$ the BMI was between $25-30 \mathrm{Kg} / \mathrm{m}^{2}$ $\left(\right.$ mean $\left.=28.4 \mathrm{Kg} / \mathrm{m}^{2}\right), 79(34.6 \%)$ had a BMI $>30 \mathrm{~kg} /$ $\mathrm{m}^{2}\left(\right.$ mean $\left.=32.1 \mathrm{Kg} / \mathrm{m}^{2}\right)$.

Sixty-nine patients $(30.3 \%)$ were males and 159 $(69.7 \%)$ females, with a mean age of 53.4 years $( \pm 13.8)$.

The most common symptomatic manifestation was hypertension $(\mathrm{n}=152,66.7 \%)$.

There were 121 right (53.1\%), 96 left (42.1\%) and 11 bilateral $(4.8 \%)$ lesions. Mean size of the gland was $4.35 \pm 2 \mathrm{~cm}$.

The anterior approach was adopted in 174 cases (76.3\%); from 2006, 33 (14.5\%) patients with left sided lesions underwent a submesocolic adrenalectomy instead of a lateral approach, requiring the mobilization of the splenic flexure. Thirteen patients (5.8\%) were operated using the flank approach.

Mean operative time was $101.5 \pm 50.9$ minutes. To better conduct the procedure, we needed to place from a minimum of four to a maximum of six ports $(4 \pm 1.5)$. Five $(1.7 \%)$ patients received the simultaneous treatment of associated conditions that required one supplementary port: three cholecystectomies and two splenectomies.

Intra-operative EMBL (estimated mean blood loss) was $110.6 \mathrm{ml} \pm 20.9(p=.756)$. No patient required intraoperative blood transfusion even in case of conversion. The conversion rate was $2.6 \%$ (six patients) mostly due to bleeding not manageable 
laparoscopically $(4,66.7 \%)$, two (33.3\%) patients needed conversions due to difficulties in the dissection of the adrenal gland from the pancreas.

Patients were allowed to have free fluid on the first post-operative day and an oral diet on the second post-operative day. Mean length of stay was $4.3 \pm 2.9$ days. The overall distribution of categorical variables is shown in Figure 1.

The complication rate was $3 \%(n=7)$. Five patients (2.2\%) had minor complications: pneumonia (2, $0.9 \%)$, hyperpyrexia $(1,0.4 \%)$, acute urinary retention $(1,0.4 \%)$ and anaemia $(1,0.4 \%)$.

One patient had a massive hemoperitoneum and needed reintervention on the second post-operative day, another developed a severe necrotic-haemorrhagic pancreatitis that required a prolonged admission.

There was no 60 -days readmission and no mortality was observed in the considered groups.

There were no statistical differences among patients grouped according to the BMI, nor for demographic, clinical or operative variables (Table 1).

Operative time was significantly lower when an electrothermal bipolar device was used $(p=<.001)$ (Table 2). We noticed that this significant difference in operative time was maintained in all three groups of patients though more evident in non-obese patients
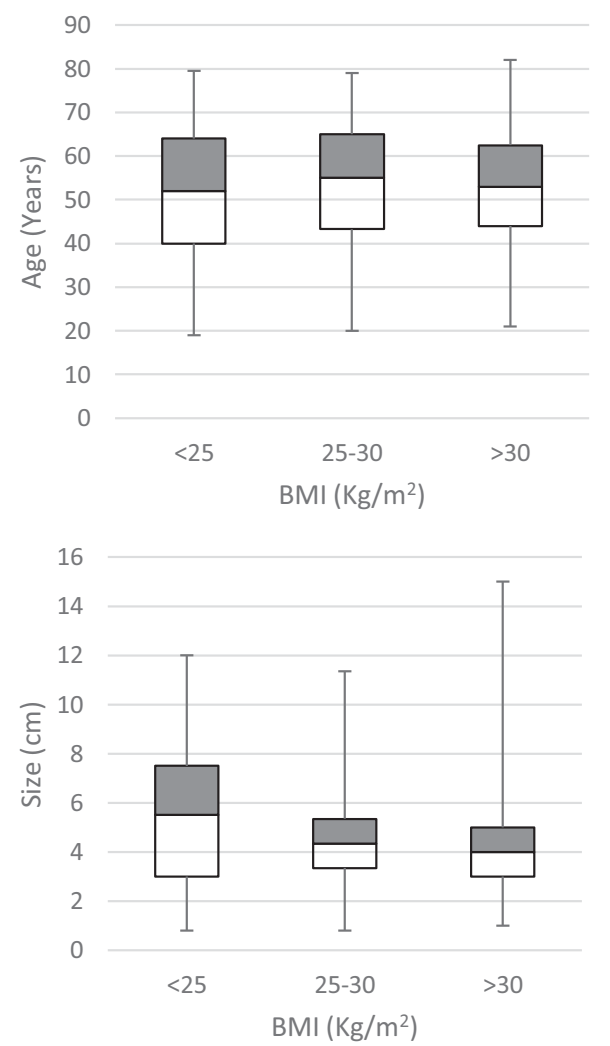

and obese patients with BMI $>30 \mathrm{Kg} / \mathrm{m}^{2}(p<.001)$ (Tables 3-5).

Logistic regression showed a statistically negative correlation between right side adrenalectomies and operative time, stronger than the correlation existing between operative time and the other analysed factors (Table 6).

Though the anterior access was always used for right laparoscopic adrenalectomy, when analysing the operative techniques used in the left adrenalectomies, we could notice a correlation between operative choices and BMI with the submesocolic access being preferred in male non-obese patients $(\mathrm{r}=1.360)$ and the anterior approach with the mobilization of the left colonic flexure in women with BMI $>30 \mathrm{Kg} / \mathrm{m}^{2}$ $(\mathrm{r}=-1.738)$ (Table 7).

Patients with BMI $>30 \mathrm{Kg} / \mathrm{m}^{2}$ showed a consistent BMI reduction of $2 \pm 1.4$ at 18 months after the operation and $5 \pm 3.2 \mathrm{~kg} / \mathrm{m}^{2}$ at the end of follow up, that was significantly different with respect to the other two groups $(1 \pm 2.7$ and $2.3 \pm 1.04 \mathrm{Vs} 0.3 \pm 1.4$ and $1.02 \pm 0.5$ respectively, $p=.047$ )

We observed the complete resolution of hypercotisolism-related symptoms in $95 \%$ of the patients; none of the patients experienced a worsening of the hypercortisolism-related symptoms in a mean follow-up of $6.3 \pm 4.2$ years.
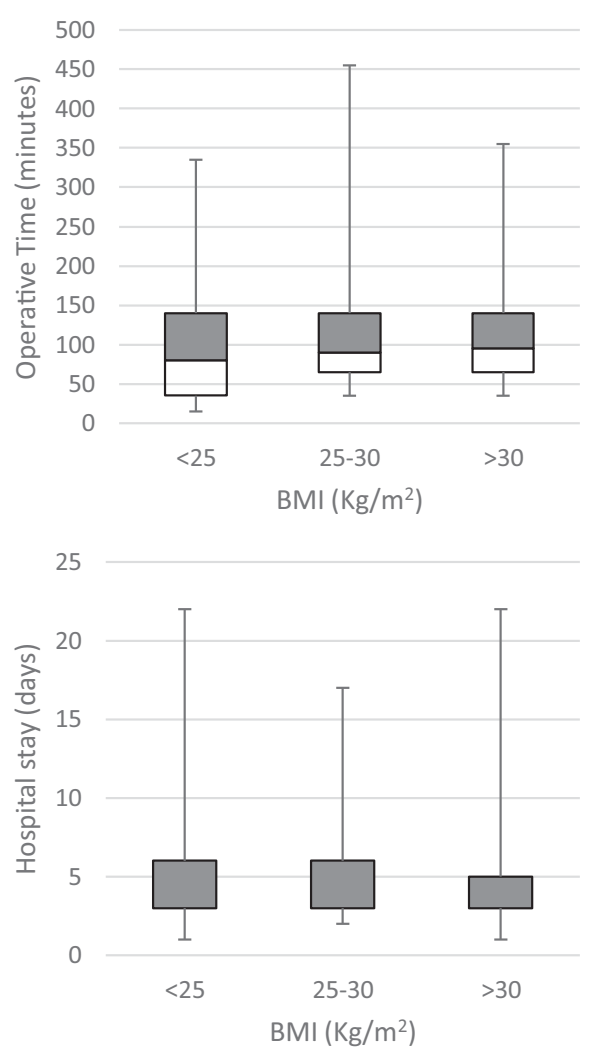

Figure 1. Distibution of age, operative time, size and hospital stay according to BMI $\left(<25 \mathrm{Kg} / \mathrm{m}^{2}, 25-30 \mathrm{Kg} / \mathrm{m}^{2},>30 \mathrm{Kg} / \mathrm{m}^{2}\right)$. 
Table 1. Comparison of the variables according to the BMI.

\begin{tabular}{|c|c|c|c|c|c|}
\hline & $\mathrm{BMI}>30 \mathrm{Kg} / \mathrm{m}^{2}(\mathrm{n}=79)$ & $25<\mathrm{BMI}<30(\mathrm{n}=62)$ & $\mathrm{BMI}<25 \mathrm{Kg} / \mathrm{m}^{2}(\mathrm{n}=87)$ & OR $(95 \% \mathrm{Cl})$ & $p$ \\
\hline Gender [male-n(\%)] & $26(32.9)$ & $15(25.8)$ & $28(32.3)$ & $0.82(0.45-1.48)$ & .533 \\
\hline Affected side & & & & & .786 \\
\hline Right [n(\%)] & $41(51.9)$ & $31(25.6)$ & $49(56.3)$ & $0.93(0.53-1.6)$ & .88 \\
\hline Left $[n(\%)]$ & $35(44.3)$ & $27(43.5)$ & 34 (39) & $1.14(066-1.99)$ & .67 \\
\hline Bilateral [n(\%)] & $3(3.8)$ & $4(6.4)$ & $4(4.6)$ & $0.69(0.17-2.69)$ & .59 \\
\hline Size $[\mathrm{cm}$-mean $( \pm S D)]$ & 4. $3( \pm 1.8)$ & $4.2( \pm 1.5)$ & $4.4( \pm 2.1)$ & & .818 \\
\hline Operative approach & & & & & .519 \\
\hline Flank approach [n(\%)] & $3(3.8)$ & $3(4.8)$ & $7(8)$ & $0.54(0.14-2)$ & .28 \\
\hline Submesocolic [n(\%)] & 11 (13.9) & $9(14.5)$ & $13(14.9)$ & $0.84(038-1.89)$ & .427 \\
\hline Anterior [n(\%)] & $64(81)$ & $44(25.3)$ & $66(75.8)$ & $1.47(0.75-2.88)$ & .166 \\
\hline OT [minutes-mean $( \pm S D)$ ] & $99.4( \pm 48.7)$ & $112.3( \pm 64.8)$ & $102.6( \pm 52.2)$ & & .919 \\
\hline \multicolumn{6}{|l|}{ Haemostatic devices } \\
\hline Electrothermal bipolar & $42(53.2)$ & $28(45.2)$ & $41(47.1)$ & $1.31(0.76-2.27)$ & .198 \\
\hline Clips [n(\%)] & $31(39.2)$ & $25(40.3)$ & $26(29.8)$ & $1.3(0.7-2.43)$ & .24 \\
\hline Ultrasonic [n(\%)] & 15 (18.9) & $9(14.5)$ & $35(40.2)$ & $0.52(0.27-1)$ & .03 \\
\hline EMBL [ml-mean $( \pm S D)]$ & $98.7( \pm 27.8)$ & $107.8( \pm 26.9)$ & $7.7( \pm 27.9)$ & & .756 \\
\hline Conversion [n(\%)] & $2(2.5)$ & $1(1.6)$ & $3(3.4)$ & $0.94(0.16-5.2$ & .655 \\
\hline PC [n (\%)] & $3(3.8)$ & $1(1.6)$ & $3(3.4)$ & $1.42(0.31-6.51)$ & .32 \\
\hline HS [days-mean $( \pm S D)]$ & $4.2( \pm 2.6)$ & $4.7( \pm 3.8)$ & $4.3( \pm 3)$ & & .881 \\
\hline
\end{tabular}

OT: operative time; EMBL: estimated mean blood loss; PC: post-operative complications; HS: hospital stay.

Table 2. Characteristics of haemostatic devices in comparison.

\begin{tabular}{lcccc}
\hline Variables & Bipolar $(\mathrm{n}=111)$ & Ultrasonic $(\mathrm{n}=61)$ & Clips $(\mathrm{n}=56)$ & $p$ \\
\hline Side right [n(\%)] & $57(51.3)$ & $30(49.2)$ & $34(60.7)$ & .287 \\
Bilateral [n(\%)] & $1(0.9)$ & $3(4.9)$ & $7(12.5)$ & .0055 \\
EMBL [ml-mean $( \pm \mathrm{SD})]$ & $8.6( \pm 26.5)$ & $17.3( \pm 53.6)$ & $11.2( \pm 48.1)$ & .268 \\
Conversions for bleeding [n(\%)] & $3(2.7)$ & $3( \pm 4.9)$ & 0 & .633 \\
Post-operative bleeding [n(\%)] & $1(0.4)$ & 0 & 0 & .486 \\
OT [min-mean $( \pm \mathrm{SD})]$ & $79.2( \pm 37.8)$ & $134.4( \pm 50.4)$ & $137.7( \pm 61.4)$ & $<.001$ \\
\hline
\end{tabular}

Table 3. Characteristics of haemostatic devices in comparison according to BMl $<25 \mathrm{~kg} / \mathrm{m}^{2}$.

\begin{tabular}{|c|c|c|c|c|c|c|c|c|}
\hline \multirow[b]{3}{*}{ Variables } & \multicolumn{8}{|c|}{$\mathrm{BMI}<25 \mathrm{Kg} / \mathrm{m}^{2}$} \\
\hline & \multicolumn{3}{|c|}{ Yes $(n=62)$} & \multicolumn{3}{|c|}{ No $(n=166)$} & \multirow[b]{2}{*}{$\begin{array}{c}\text { OR } \\
(95 \% \mathrm{Cl})\end{array}$} & \multirow[b]{2}{*}{$p$} \\
\hline & $\begin{array}{l}\text { Bipolar } \\
(n=28)\end{array}$ & $\begin{array}{l}\text { Ultrasonic } \\
(\mathrm{n}=9)\end{array}$ & $\begin{array}{c}\text { Clips } \\
(\mathrm{n}=25)\end{array}$ & $\begin{array}{l}\text { Bipolar } \\
(\mathrm{n}=83)\end{array}$ & $\begin{array}{l}\text { Ultrasonic } \\
(\mathrm{n}=26)\end{array}$ & $\begin{array}{c}\text { Clips } \\
(n=57)\end{array}$ & & \\
\hline Right side [n(\%)] & $15(53.6)$ & $5(55.5)$ & $11(44)$ & $28(33.7)$ & $14(53.8)$ & $34(59.6)$ & $0.53(0.20-1.35)$ & .231 \\
\hline Bilateral $[n(\%)]$ & 1 & 0 & $1(16)$ & $1(1,2)$ & $1(34.6)$ & $7(8.8)$ & $1.98(0.48-8.10)$ & .444 \\
\hline EMBL [ml-mean $( \pm S D)]^{*}$ & $6.8( \pm 13.1)$ & $11.1( \pm 28.6)$ & $8.9( \pm 32.9)$ & $9.3( \pm 25.2)$ & $15.3( \pm 48.3)$ & $13.1(44.2)$ & & .786 \\
\hline Conversions for bleeding [ $\mathrm{n}(\%)]$ & 0 & $1(11.1)$ & 0 & $3(3.6)$ & $2(7.7)$ & 0 & $0.67(0.33-3.58)$ & .456 \\
\hline Post-operative bleeding [ $\mathrm{n}(\%)]$ & 0 & 0 & 0 & $1(1,2)$ & 0 & 0 & $1.03(0.11-5.20)$ & .293 \\
\hline OT $[\text { min-mean }( \pm S D)]^{*}$ & $68.3( \pm 19.2)$ & $130( \pm 16.4)$ & $128( \pm 32.1)$ & $82.9( \pm 28.2)$ & $135.9( \pm 20.9)$ & $160.9( \pm 41)$ & & $<.001$ \\
\hline
\end{tabular}

Fisher exact test; ${ }^{*}$ Wilcoxon rank sum test.

Table 4. Characteristics of haemostatic devices in comparison according to the $25 \mathrm{Kg} / \mathrm{m}^{2}>\mathrm{BMI}<30 \mathrm{Kg} / \mathrm{m}^{2}$.

\begin{tabular}{|c|c|c|c|c|c|c|c|c|}
\hline \multirow[b]{3}{*}{ Variables } & \multicolumn{8}{|c|}{$25 \mathrm{Kg} / \mathrm{m}^{2}>\mathrm{BMI}<30 \mathrm{Kg} / \mathrm{m}^{2}$} \\
\hline & \multicolumn{3}{|c|}{ Yes $(n=87)$} & \multicolumn{3}{|c|}{ No $(n=141)$} & \multirow[b]{2}{*}{ OR $(95 \% \mathrm{Cl})$} & \multirow[b]{2}{*}{$p$} \\
\hline & Bipolar $(n=44)$ & $\begin{array}{l}\text { Ultrasonic } \\
(\mathrm{n}=7)\end{array}$ & Clips $(n=36)$ & Bipolar $(n=71)$ & $\begin{array}{l}\text { Ultrasonic } \\
(\mathrm{n}=28)\end{array}$ & Clips $(n=42)$ & & \\
\hline Right side $[\mathrm{n}(\%)]$ & $23(52.3)$ & $4(51.1)$ & $20(5.5)$ & 31 (43.7) & 15 (53.6) & $25(59.5)$ & $1.98(0.48-8.1)$ & .819 \\
\hline Bilateral $[n(\%)]$ & $1(2.3)$ & 0 & $1(2.8)$ & 0 & $1(3.6)$ & $7(16.7)$ & $2.85(0.55-14.74)$ & .288 \\
\hline EMBL [ml-mean $( \pm S D)]^{*}$ & $8.9( \pm 17.3)$ & $18( \pm 38.7)$ & $13.9( \pm 25.6)$ & $7.9( \pm 25.9)$ & $15.2( \pm 58.2)$ & $17.1( \pm 52.3)$ & & .422 \\
\hline $\begin{array}{l}\text { Conversions for } \\
\text { bleeding [n(\%)] }\end{array}$ & $2(4.5)$ & 0 & 0 & $1(1.4)$ & $3(10.7)$ & 0 & $0.29(0.02-3.31)$ & .635 \\
\hline $\begin{array}{l}\text { Post-operative } \\
\quad \text { bleeding }[\mathrm{n}(\%)]\end{array}$ & 0 & 0 & 0 & 1 & 0 & 0 & $1.51(0.15-14.97)$ & .592 \\
\hline OT $[\text { min-mean }( \pm S D)]^{*}$ & $75.4( \pm 20)$ & $135.9( \pm 24.4)$ & $144( \pm 33)$ & $82.3( \pm 27.3)$ & $128.6( \pm 7.4)$ & $123( \pm 36)$ & & .418 \\
\hline
\end{tabular}

Fisher exact test; ${ }^{*}$ Wilcoxon rank sum test. 
Table 5. Characteristics of haemostatic devices in comparison according to BMI $>30 \mathrm{Kg} / \mathrm{m}^{2}$.

\begin{tabular}{|c|c|c|c|c|c|c|c|c|}
\hline \multirow[b]{3}{*}{ Variables } & \multicolumn{8}{|c|}{$\mathrm{BMI}<30 \mathrm{Kg} / \mathrm{m}^{2}$} \\
\hline & \multicolumn{3}{|c|}{ Yes $(n=79)$} & \multicolumn{3}{|c|}{ No $(n=149)$} & \multirow[b]{2}{*}{ OR $(95 \% \mathrm{Cl})$} & \multirow[b]{2}{*}{$p$} \\
\hline & Bipolar $(n=39)$ & $\begin{array}{l}\text { Ultrasonic } \\
(\mathrm{n}=19)\end{array}$ & Clips $(n=21)$ & Bipolar $(n=72)$ & $\begin{array}{l}\text { Ultrasonic } \\
(\mathrm{n}=16)\end{array}$ & Clips $(n=61)$ & & \\
\hline Right side [n(\%)] & $5(12.8)$ & $10(52.6)$ & $14(66.7)$ & $22(30.5)$ & $3(18.7)$ & $17(27.8)$ & $0.80(0.33-1.98)$ & .665 \\
\hline Bilateral [n(\%)] & $1(2.6)$ & $1(5.3)$ & $6(28.6)$ & $1(1.4)$ & 0 & $2(3.3)$ & $0.69(0.17-2.69)$ & .331 \\
\hline $\begin{array}{l}\text { EMBL } \\
\qquad[\mathrm{ml}-\text { mean }( \pm \mathrm{SD})]^{*}\end{array}$ & $8.9( \pm 25.3)$ & $28.8( \pm 43.6)$ & $17.9( \pm 41.1)$ & $12.5( \pm 23.6)$ & $21.3( \pm 38.2)$ & $16.8( \pm 39.8)$ & $0.84(0.32-1.78)$ & .782 \\
\hline $\begin{array}{l}\text { Conversions for } \\
\text { bleeding [n(\%)] }\end{array}$ & $1(2.6)$ & $2(1.5)$ & 0 & $2(2.8)$ & $1(6.25)$ & 0 & $1.37(0.22-8.52)$ & .532 \\
\hline $\begin{array}{l}\text { Post-operative bleed- } \\
\text { ing }[\mathrm{n}(\%)]\end{array}$ & $1(2.6)$ & 0 & 0 & 0 & 0 & 0 & $1.01(0.12-1.45)$ & .221 \\
\hline $\begin{array}{l}\text { OT }[\text { min- } \\
\text { mean }( \pm S D)]^{*}\end{array}$ & $86( \pm 21.1)$ & $120( \pm 5.7)$ & $128.3( \pm 40.9)$ & $126.8( \pm 16.1)$ & $103.5( \pm 33.3)$ & $90.4( \pm 19.7)$ & & $<.001$ \\
\hline
\end{tabular}

Fisher exact test; ${ }^{*}$ Wilcoxon rank sum test.

Table 6. Effects of BMI, surgical haemostatic devices, side and size of the lesions on operative time.

\begin{tabular}{lclr}
\hline & $r$ coefficient & \multicolumn{1}{c}{ OR (95\% Cl) } & \multicolumn{1}{c}{$p$} \\
\hline $\mathrm{BMI}<25 \mathrm{Kg} / \mathrm{m}^{2}$ & 0.076 & $0.37(0.02-0.56)$ & .315 \\
$25 \mathrm{Kg} / \mathrm{m}^{2}<\mathrm{BMl}<30 \mathrm{Kg} / \mathrm{m}^{2}$ & 0.005 & $0.08(0.01-1.05)$ & .938 \\
$\mathrm{BMI}>30 \mathrm{Kg} / \mathrm{m}^{2}$ & -0.018 & $0.23(0.07-0.49)$ & .812 \\
Bipolar vs clips & -2.713 & $0.06(0.029-0.14)$ & $<.001$ \\
Bipolar vs Ultrasonic & -1.898 & $0.14(0.07-0.3)$ & $<.001$ \\
Ultrasonic Vs clips & 2.71 & $15.17(6.88-33.4)$ & $<.001$ \\
Right vs left & -14.67 & $10.5(9.67-19.4)$ & .057 \\
Anterior vs flank & 2.03 & $7.634(2.85-20.4)$ & $<.001$ \\
Anterior vs submesocolic & 0.072 & $1.075(0.44-2.61)$ & .982 \\
Submesocolic vs flank & -2.28 & $0.1(0.03-0.34)$ & .167 \\
Size $>4$ vs $<4$ & 0.012 & $0.07(0.001-0.19)$ & .088 \\
\hline
\end{tabular}

We observed a mean decrease in arterial pressure of $15 \mathrm{mmHg}( \pm 5.2)$.

Fasting glucose and oral glucose tolerance test showed an overall mean decrease of $28 \mathrm{mg} / \mathrm{dL}( \pm 6.2)$ and $22.1 \mathrm{mg} / \mathrm{dL}( \pm 1.3)$, respectively.

Serum cortisol at 8:00 AM decreased by a mean of 4.1 and $7.2 \mathrm{mcg} / \mathrm{dL}$ after dexamethasone.

We also observed a mean decrease of $5 \mathrm{Kg} / \mathrm{m}^{2} \pm$ 3.2 of BMI in obese patients in the subsequent 18 months from the operation.

\section{Discussion}

The difficulties of laparoscopic surgical procedures in obese patients have been previously described [5-7]. Increased central and visceral adiposity also lead to intraoperative technical challenges during laparoscopic adrenalectomy, which may be responsible for prolonged operative times and higher conversion rates $[5,7,14]$. Moreover, obese patients undergoing adrenalectomy have a greater rate of comorbid disease and a higher risk of perioperative complications [5].

In addition to this, Cushing's syndrome itself has been identified as a negative prognostic factor since the chronic hypercortisolism, both subclinical or symptomatic, has been shown to adversely affect perioperative outcomes after various general operations, including adrenalectomy [14].

Kazaure et al., in a revision of 1,629 patients undergoing adrenalectomy for Cushing's syndrome [6], found statistically significant differences in the distribution of BMI in different groups of age, gender and race with black men aged 18-44 being more likely morbidly obese patients. The overall complication rate was $7.3 \%$ and there were significant differences in occurrence of wound complications when BMI groups were compared $(p<.001)$. Obese and morbidly obese patients were more likely to have superficial, deep wound and septic complications than nonobese patients $(p=.002)$. The authors concluded that morbid obesity can be considered an independent predictor of postoperative wound and septic complications and longer operative time (OR 2.9, 95\% CI: $1.7-5.7, p<.001)$, as well as other negative prognostic factors such as: a history of peripheral vascular disease (OR 17.7, 95\% CI: 3.4-92.8, $p<.001$ ) and having an open procedure (OR 6.3, 95\% CI: 3.0-12.9, $p<.001$ ), admission from an acute or chronic care facility (OR 9.5, 95\% CI: 2.6-34.7, $p=.001$ ), presence of a preoperative open wound (OR 6.9, 95\% CI: $1.5-32.2 ; p=.014)$, and receiving a transfusion of at least one unit of blood intraoperatively (OR 5.5, 95\% CI: 2.1-13.9, p0.001).

However, the present literature is not concord, and other authors attested the feasibility of the laparoscopic approach even in obese patients [15]. In another study, published by Peditziwiatr in 2015 and including 520 consecutive patients undergoing laparoscopic adrenalectomy, the authors failed to demonstrate that BMI could affect operative time $(p=.1444)$, complication rate $(p=.5295)$ and the conversion rate $(p=.6524)$ They therefore concluded that obesity has no influence on short-term outcomes of laparoscopic adrenalectomy. 
Table 7. Effects of BMI, gender and age on the choice of operative approach for left laparoscopic adrenalectomy.

\begin{tabular}{lccc}
\hline & Anterior approach $(r)$ & Submesocolic approach $(r)$ & $p$ \\
\hline $\mathrm{BMl}<25 \mathrm{Kg} / \mathrm{m}^{2}$ & -0.073 & 2.362 & .247 \\
$25 \mathrm{Kg} / \mathrm{m}^{2}<\mathrm{BMl}<30 \mathrm{Kg} / \mathrm{m}^{2}$ & -0.072 & 0.138 & .006 \\
$\mathrm{BMl}>30 \mathrm{Kg} / \mathrm{m}^{2}$ & 0.720 & -0.019 & .026 \\
$\mathrm{M}$ Vs F $\left(\mathrm{BMl}<25 \mathrm{Kg} / \mathrm{m}^{2}\right)$ & 0.001 & 1.360 & .532 \\
$\mathrm{M}$ Vs F $\left(25 \mathrm{Kg} / \mathrm{m}^{2}<\mathrm{BMl}<30 \mathrm{Kg} / \mathrm{m}^{2}\right)$ & 0.068 & 0.092 & .335 \\
$\mathrm{M}$ Vs F $\left(\mathrm{BMI}>30 \mathrm{Kg} / \mathrm{m}^{2}\right)$ & -1.738 & -0.018 & .074 \\
Size $>4 \mathrm{~cm} \mathrm{Vs}<4 \mathrm{~cm}$ & -0.129 & 0.113 & .026 \\
\hline
\end{tabular}

Interestingly, we did not observe any statistical differences between the identified groups and BMI did not correlate with a longer operative time. Minimally invasive techniques are the preferred procedures to excise most of the tumours because, aside from better post-operative outcomes, they offer technical advantage, allowing a better and magnified view of deep spaces. In our opinion, this advantage is even more evident in case of obesity, when the correct exposure of the working field is made more difficult by excessive abdominal fat.

However, we noticed a difference in the choice of the operative technique for left adrenalectomy. In our series the surgeon preferred to mobilize the splenic flexure to reach the left adrenal gland in women with BMI $>30 \mathrm{Kg} / \mathrm{m}^{2}$, suggesting that the distribution of visceral fat in these patients could constitute a drawback for the submesocolic approach.

We otherwise found a statistical difference in operative times according to the choice of haemostatic devices. In our opinion, this reflects the more careful and longer dissection needed to correctly apply laparoscopic clips on adrenal vein. More important, the difference was maintained even when the BMI was $>30 \mathrm{Kg} / \mathrm{m}^{2}$.

The reduction of operative times may be crucial in obese patients, who have multiple comorbid conditions, including respiratory and cardiovascular function impairment, that limit their ability to tolerate longer operations. Another issue to be considered is the approach chosen to reach the adrenal gland. Worldwide, transabdominal laparoscopic or posterior retroperitoneoscopic are two of the more common routes to adrenalectomy [15-17]. Recent meta-analyses showed no statistical differences between laparoscopic and retroperitoneoscopic access regarding perioperative outcomes; however, postoperative recovery was slightly faster in the latter [16-19].

Previous studies showed that the retroperitoneoscopic approach is safe and feasible for patients with prior extensive abdominal surgery and for bilateral adrenalectomy. With the retroperitoneoscopic approach the need for repositioning is avoided but, on the other hand, the disadvantage of this technique is that it requires the prone position. Obese patients, due to the simultaneous comorbities previously mentioned, may even have a limited tolerance to the prone or jack-knife positions or the increased $\mathrm{CO}_{2}$ insufflation pressures that are required for such approaches. Furthermore, all patients with Cushing's syndrome have extensive retroperitoneal fat and the posterior approach is made more disadvantageous by such morphological characteristics $[3,18]$. Therefore, we choose to adopt in all the patients the transabdominal approach without noticing any difference in the operative outcomes. In addition, this approach allowed us to have a quick conversion and to perform associated operative procedures or contralateral adrenalectomy, when needed, without repositioning the patients.

As a final result we noticed that the benefits of unilateral laparoscopic adrenalectomy in patients with Cushing's syndrome could be extended to the improvements and in some cases to the resolution of hypercortisolism related symptoms (i.e hypertension or even morbid obesity) [10,13].

The higher the BMI was before surgery the more significant was its reduction after surgery.

\section{Conclusion}

In conclusion, our analysis showed showed two main results. The first is that morbid obesity has no influence on short-term outcomes of laparoscopic transperitoneal approach. In addition, the use of an elechtrotermal energy device allows a quicker dissection in respect of other haemostatic devices.

\section{Declaration of interest}

The authors do not have any conflicts of interest.

\section{ORCID}

Andrea Balla (D) http://orcid.org/0000-0002-0182-8761 


\section{References}

[1] Lacroix A, Feelders RA, Stratakis CA, et al. Cushing's syndrome. The Lancet. 2015;386:913-927.

[2] Valassi E, Santos A, Yaneva M, et al. ERCUSYN Study Group. The European Registry on Cushing's syndrome: 2-year experience. Baseline demographic and clinical characteristics. Eur J Endocrinol. 2011; 165:383-392.

[3] Newell-Price J, Bertagna X, Grossman AB, et al. Cushing's syndrome. Lancet. 2006;367:1605-1617.

[4] Nieman LK, Biller BM, Findling JW, et al. The diagnosis of Cushing's syndrome: an Endocrine Society clinical practice guideline. J Clin Endocrinol Metab. 2008;93:1526.

[5] Dancea HC, Obradovic V, Sartorius J, et al. Increased complication rate in obese patients undergoing laparoscopic adrenalectomy. JSLS. 2012;16: 45-49.

[6] Kazaure HS, Roman SA, Sosa JA. Obesity is a predictor of morbidity in 1,629 patients who underwent adrenalectomy. World J Surg. 2011;35:1287-1295.

[7] Erbil Y, Barbaros U, Sari S, et al. The effect of retroperitoneal fat mass on surgicaloutcomes in patients performing laparoscopic adrenalectomy: the effect of fat tissue in adrenalectomy. Surg Innov. 2010;2: 114-119.

[8] Kratz A, Ferraro M, Sluss PM, et al. Laboratory reference values. N Engl J Med. 2004;351:1548-1563.

[9] Nieman L, Biller B, Findling J, et al. The diagnosis of Cushing's syndrome: an endocrine society clinical practice guideline. Eur J Endocrinol. 2008,93: 1526-1540.

[10] Chiodini I, Morelli V, Salcuni AS, et al. Beneficial metabolic effects of prompt surgical treatment in patients with an adrenal incidentaloma causing biochemical hypercortisolism. J Clin Endrocinol Metabol. 2010,95:2736-2745.
[11] Lezoche G, Baldarelli M, Cappelletti Trombettoni $\mathrm{MM}$, et al. Two decades of laparoscopic adrenalectomy: 326 procedures in a single-center experience. Surg Laparosc Endosc Percutan Tech. 2016;26: 128-132.

[12] Vidal J. Updated review on the benefits of weight loss. Int J Obes Relat Metab Disord. 2002;25: S25-S28 38.

[13] Mancia G, De Backer G, Dominiczak A, et al. ESHESC practice guidelines for the management of arterial hypertension: ESH-ESC task force on the management of arterial hypertension. J Hypertens. 2007;25:1105-1187.

[14] Shariq OA, Fruth KM, Hanson KT, et al. Metabolic syndrome is associated with increased postoperative complications and use of hospital resources in patients undergoing laparoscopic adrenalectomy. Surgery. 2018;163:167-175.

[15] Pedziwiatr $M$, Major P, Pisarska $M$, et al. Laparoscopic transperitoneal adrenalectomy in morbidly obese patients is not associated with worse short-term outcomes. Int J Urol. 2017;24:59-63.

[16] Zonča $P$, Bužga $M$, Ihnát $P$, et al. Retroperitoneoscopic adrenalectomy in obese patients: is it suitable? Obesity Surg. 2015;25: 1203-1208.

[17] Paganini AM, Guerrieri M, Balla A, et al. Management of adrenal incidentaloma by laparoscopic transperitoneal anterior and submesocolic approach. Langenbeck's Arch Surg. 2016;401:71-79.

[18] Constantinides VA, Christakis I, Touska P, et al. Systematic review and meta-analysis of retroperitoneoscopic versus laparoscopic adrenalectomy. $\mathrm{Br} \mathrm{J}$ Surg. 2012;99:1639-1648.

[19] Nigri G, Rosman AS, Petrucciani N, et al. Meta-analysis of trials comparing laparoscopic transperitoneal and retroperitoneal adrenalectomy. Surgery. 2013; 153:111-119. 